\title{
De redelijke grond: rechtsfeit of rechtsgrond?
}

\author{
mr. Marko Jovović en mr. Joren Wiewel*
}

\section{Inleiding}

Op 16 februari 2018 wees de Hoge Raad twee beschikkingen $^{1}$ waarin de toepasselijkheid van de wettelijke bewijsregels bij ontbindingszaken aan bod kwam. Deze beschikkingen zijn uitgebreid besproken en geanalyseerd in de literatuur. ${ }^{2}$ In beide beschikkingen heeft de Hoge Raad uitspraak gedaan over de wijze waarop dient te worden vastgesteld of sprake is van een redelijke grond zoals bedoeld in artikel 7:669 lid 3 onder $\mathrm{ct} / \mathrm{m} \mathrm{h}$ BW (hierna: de 'redelijke gronden'). In het licht van de discussie over de vraag of redelijke gronden ambtshalve moeten worden toegepast in de ontbindingsprocedure, ${ }^{3}$ roepen de 16 februari-beschikkingen bij ons de vraag op of een redelijke grond moet worden gezien als 'rechtsfeit' of als een 'rechtsgrond'. Het onderscheid is relevant vanwege de systematiek van de artikelen 24 en 25 van het Wetboek van Burgerlijke Rechtsvordering (hierna:

' $\mathrm{Rv}$ '). Zijn de redelijke gronden immers rechtsfeiten, dan brengt artikel $24 \mathrm{Rv}$ mee dat de rechter een arbeidsovereenkomst niet mag ontbinden op een andere grond dan die welke de werkgever aan zijn verzoek ten grondslag heeft gelegd. Zijn de redelijke gronden echter rechtsgronden, dan mag dat binnen bepaalde grenzen wel. $^{4}$

Het onderscheid lijkt academisch, maar is van belang voor de praktijk en voor het systeem van het ontslagrecht. Zo gaat de regering er, blijkens de conceptmemorie van toelichting bij het voorgestelde Wetsvoor-

* Marko Jovović en Joren Wiewel zijn beiden advocaat bij Stibbe in Amsterdam.

1. HR 16 februari 2018, ECLI:NL:HR:2018:182 (Decor Handelsmaatschappij) en HR 16 februari 2018, ECLI:NL:HR:2018:220 (Bossers \& Cnossen).

2. Zie onder meer: J.W. Alt, 'Bewijzen en aannemelijk maken: een wereld van verschil', Advocatenblad 2018/5, p. 51-53; D.J. Buijs, 'Voor de toepassing van de ontbindingsgrond verstoorde arbeidsverhouding is niet vereist dat sprake is van enige verwijtbaarheid', TRA 2018/41; C.J. Frikkee, 'Disfunctioneren en de Hoge Raad: stellen en zo nodig bewijzen', TRA 2018/49; F.G. Laagland, 'Bewijzen in de ontbindingsprocedure', Annotaties AR 2018-0214 en J.M. van Slooten, 'Bewijsrecht en aannemelijkheidsoordelen in arbeidsrechtelijke ontbindingsprocedures', Ondernemingsrecht 2018/50.

3. Zie o.a. Vestering en Wetzels, Praktisch arbeidsprocesrecht onder de WWZ, Den Haag: Sdu Uitgevers 2018, p. 44-45; J.H. Bennaars \& J.P. Quist, 'Ambtshalve aanvulling van rechtsgronden in de ontbindingsprocedure?', TAP 2018/99; VAAN - VVA Notitie van de Werkgroep Internetconsultatie WAB, p. 36

4. Zie bijv. J.H. Bennaars \& J.P. Quist, 'Ambtshalve aanvulling van rechtsgronden in de ontbindingsprocedure?', TAP 2018/99. stel arbeidsmarkt in balans (hierna: de 'Wab'), ${ }^{5}$ van uit dat de redelijke gronden rechtsgronden zijn. De minister heeft in het gedeelte van de concept-memorie van toelichting waarin de cumulatiegrond wordt geintroduceerd, overwogen dat '[d]e cumulatiegrond, net als de andere redelijke gronden, ook ambtshalve door de rechter kan worden toegepast.' Indien een redelijke grond een rechtsfeit is, staat die overweging haaks op het in artikel $24 \mathrm{Rv}$ neergelegde verbod op rechterlijke aanvulling van de feitelijke grondslag.

In dit artikel bespreken wij eerst de 16-februari-beschikkingen en behandelen wij deze in het licht van de artikelen 24 en $25 \mathrm{Rv}$. Daarna bespreken wij de systematiek van de voorgestelde cumulatiegrond van het Wetsvoorstel Wab. Tot slot stippen wij kort de mogelijke betekenis voor de Wab aan van de wetsopvatting van de Hoge Raad die (naar wij betogen) ten grondslag ligt aan de 16februari-beschikkingen.

\section{De 16-februari- beschikkingen}

\subsection{De hoven: aannemelijk maken van redelijke gronden}

In beide 16-februari-beschikkingen had het hof geoordeeld dat voor ontbinding van de arbeidsovereenkomst kon worden volstaan met het 'aannemelijk maken van de redelijke grond'.

De eerste beschikking ${ }^{6}$ (hierna: de 'Decor-beschikking') betreft de vraag of een werknemer disfunctioneerde. Het Hof Den Bosch oordeelde dat de werkgever voldoende annemelijk had gemaakt dat sprake was van ongeschiktheid van de werknemer voor zijn functie, en dat de werknemer voldoende in de gelegenheid was gesteld zijn functioneren te verbeteren. Het hof stelde daarbij een aantal uitgangspunten voorop. Ten eerste dat de kantonrechter de arbeidsovereenkomst kan ontbinden indien voldaan is aan de vereisten van artikel 7:669 lid 1 jo. lid 3 aanhef en onder g BW. Ten tweede dat deze vereisten zijn ontleend aan het tot 1 juli 2015 geldende Ontslagbesluit. ${ }^{7}$ Ten derde stelde het hof

5. Conceptvoorstel van wet tot wijziging van Boek 7 van het Burgerlijk Wetboek, de Wet allocatie arbeidskrachten door intermediairs, de Wet financiering sociale verzekeringen en enige andere wetten om de balans tussen vaste en flexibele arbeidsovereenkomsten te verbeteren (Wet arbeidsmarkt in balans), zie: www.internetconsultatie.nl/arbeidsmarkt_ in_balans.

6. HR 16 februari 2018, ECLI:NL:HR:2018:182 (Decor Handelsmaatschappij).

7. Stcrt. 1998, 328. 
voorop dat uit de parlementaire geschiedenis blijkt dat het in eerste instantie aan de werkgever is om te beoordelen of een werknemer nog voldoet aan de eisen die aan een functie worden gesteld. Het hof overwoog dat tegelijkertijd niet mag worden ontbonden wanneer een werkgever, gezien de aangevoerde argumenten voor het ontslag, niet in redelijkheid tot zijn besluit heeft kunnen komen, of zelf ook blaam treft. Uit dit alles leidde het hof af dat een werkgever 'dus niet ieder afzonderlijk kritiekpunt op het functioneren [zal] hoeven te bewijzen; hij heeft een eigen beoordelingsvrijheid, die echter wel de toets der kritiek moet kunnen doorstaan voor wat betreft de redelijkheid daarvan. Om die reden kan een werkgever in de regel volstaan met het aannemelijk maken van de hier aan de orde zijnde ontslaggrond (de "d-grond").'

In de tweede beschikking' (hierna: de 'B\&C-beschikking') ontbond het hof de arbeidsovereenkomst van de werknemer op de g-grond nu 'voldoende aannemelijk was geworden dat zowel de samenwerking met collega's als de verhouding met leidinggevenden en de directie in de loop der tijd zodanig verslechterd is dat sprake is van een arbeidsverhouding die ernstig en duurzaam is verstoord.'

\subsection{De cassatiemiddelen: aannemelijk maken redelijke grond niet afdoende}

Zoals Van Slooten al signaleerde ${ }^{10}$ was het tegen de achtergrond van de Mediant-beschikking ${ }^{11}$ niet gek dat beide werknemers in cassatie gingen. In hun cassatiemiddelen gingen beide werknemers ervan uit dat de aanwezigheid van de redelijke grond bewezen moet worden. De werknemer uit de Decor-beschikking voerde als cassatiemiddel aan dat de rechter de arbeidsovereenkomst slechts kan ontbinden indien is voldaan aan de volgende elementen: (a) er is ongeschiktheid van de werknemer tot het verrichten van de bedongen arbeid; die (b) niet door ziekte of gebreken komt; mits (c) de werkgever de werknemer hiervan tijdig in kennis heeft gesteld teneinde zijn functioneren te verbeteren; en (d) de ongeschiktheid niet het gevolg is van onvoldoende zorg van de werkgever voor scholing van de werknemer of voor de arbeidsomstandigheden van de werknemer; en (e) herplaatsing binnen een redelijke termijn, al dan niet met behulp van scholing, in een andere passende functie niet mogelijk is of niet in de rede ligt.

Volgens het cassatiemiddel dient de werkgever deze vijf hoofdelementen te stellen, en zo nodig te bewijzen. Het hof had de verkeerde maatstaf aangelegd door te overwegen dat de werkgever in de regel kan volstaan met het 'aannemelijk maken' van de aan de orde zijnde redelijke grond. De werknemer baseerde zich hierbij op de Mediant-beschikking, waarin de Hoge Raad oordeelde

8. Hof Den Bosch 3 november 2016, ECLI:NL:GHSHE:2016:4919, JAR 2016/300 m.nt. Van Tuyll van Serooskerken, r.o. 3.7.

9. HR 16 februari 2018, ECLI:NL:HR:2018:220 (Bossers \& Cnossen).

10. J.M. van Slooten, 'Bewijsrecht en aannemelijkheidsoordelen in arbeidsrechtelijke ontbindingsprocedures', Ondernemingsrecht 2018/50.

11. HR 23 december 2016, ECLI:NL:HR:2016:2998, NJ 2017/2013 m.nt. Verhulp (Mediant). dat het bewijsrecht in ontbindingsprocedures in beginsel onverkort van toepassing is. ${ }^{12}$

Ook in het cassatieverzoek dat leidde tot de B\&Cbeschikking voerde de werknemer onder verwijzing naar de Mediant-beschikking aan dat het hof ten onrechte de ernstige en duurzame verstoring 'aannemelijk achtte': 'Weliswaar heeft Bossers \& Cnossen die verstoring gesteld, maar J. heeft die verstoring zowel in eerste aanleg, alsook in het verweerschrift in appel gemotiveerd betwist (cursivering werknemer).' ${ }^{13}$

In beide zaken gingen de werknemers er dus van uit dat de aanwezigheid van een redelijke grond een (rechts)feit is dat ingevolge het wettelijke stelsel van de artikelen 149 en $150 \mathrm{Rv}$ dient te worden gesteld en, bij voldoende gemotiveerde betwisting, bewezen. Daaruit leidden zij af dat de hoven een verkeerde bewijsmaatstaf hadden aangelegd door te oordelen dat de aanwezigheid van de redelijke grond aannemelijk was geworden.

\subsection{Conclusies A-G: aannemelijkheid juiste bewijsmaatstaf redelijke grond}

De procesrechtelijke vraag die in cassatie voorlag, was dus of de hoven het bewijsrecht juist hadden toegepast door de aanwezigheid van de redelijke grond aannemelijk te achten. De Hoge Raad gaat minder uitgebreid in op dit onderwerp dan de A-G dat doet, maar verwijst in zijn oordeel wel naar de relevante passages uit de conclusies. Beide conclusies komen wat de procesrechtelijke aspecten betreft nagenoeg overeen, vermoedelijk omdat beide werknemers hadden aangevoerd dat het bewijsrecht onjuist door de hoven was toegepast. ${ }^{14} \mathrm{Wij}$ bespreken de conclusies dan ook gezamenlijk.

De A-G stelde voorop dat de Hoge Raad in de Mediantbeschikking heeft beslist dat in een ontbindingsprocedure de wettelijke bewijsregels van toepassing zijn. Dit brengt onder meer mee dat het - in beginsel - niet voldoende is dat feiten ${ }^{15}$ aannemelijk zijn, maar dat feiten moeten zijn bewezen. Wat is nu het verschil tussen aannemelijk zijn en bewezen zijn?

Volgens de A-G wordt algemeen aangenomen dat het voor de civiele rechter voldoende is om een redelijke mate van zekerheid te hebben dat een feit zich heeft voorgedaan, oftewel dat feiten 'in voldoende mate zijn komen vast te staan'. Dit kan het geval zijn wanneer een feit 'aannemelijk' is. Aannemelijkheid van feiten kan op twee verschillende maar verwante zaken duiden. De eerste mogelijkheid is dat de rechter een lichter bewijsrech-

12. HR 16 februari 2018, ECLI:NL:HR:2018:182, RvdW 2018/270 (Decor Handelsmaatschappij), cassatiemiddel, randnummers 4-9.

13. HR 16 februari 2018, ECLI:NL:HR:2018:220 RvdW 2018/271 (Bossers \& Cnossen), cassatiemiddel, randnummer 2.1.3.

14. Concl. A-G bij de Decor-beschikking, ECLI:NL:PHR:2017:1058 en Concl. A-G bij de B\&C-beschikking 10 november 2017, ECLI:NL:PHR: 2017:1256

15. De focus van de A-G op 'feiten' is interessant, aangezien de cassatiemiddelen de vraag aan de orde stellen op welke wijze redelijke gronden bewezen dienen te worden. 
telijk regime heeft toegepast. ${ }^{16}$ De tweede mogelijkheid is dat het om feiten gaat die naar hun aard moeilijk bewijsbaar zijn. Het gaat als het ware om 'feiten' die een natuurwetenschapper niet als 'feit' zou herkennen. Deze feiten kúnnen niet waargenomen worden en het is dus ook niet mogelijk ze in empirische zin te bewijzen. Partijen kunnen zulke feiten slechts bewijzen door aannemelijk te maken dat zij redelijkerwijs zijn af te leiden uit andere, meer 'harde' feiten. Omdat het te bewijzen feit een gevolgtrekking is, kan daarover altijd discussie en onzekerheid blijven bestaan. Het maximaal haalbare is dan dat feiten en omstandigheden worden bewezen, waaruit redelijkerwijs af te leiden is dat het te bewijzen feit zich heeft voorgedaan. Het bewijs slaagt als het te bewijzen feit '(voldoende) aannemelijk' is gemaakt. Bij de beoordeling of dat het geval is, komt het ook hier 'uiteindelijk aan op een waardering en afweging van de argumenten die in het processuele debat door partijen over en weer zijn aangevoerd,' aldus de A-G. ${ }^{17}$ Dit is volgens de A-G de reden dat bewijsopdrachten in rechterlijke uitspraken vaak inhouden dat 'bewijs wordt opgedragen van feiten of omstandigheden waaruit volgt dat ...'.

Wat betekent dit voor de bewijsmaatstaf die dient te worden aangelegd bij de beoordeling of een werknemer disfunctioneerde in de zin van artikel 7:669 lid 3 onder $\mathrm{d}$ BW of voor de vraag of sprake is van een verstoorde arbeidsverhouding in de zin van artikel 7:669 lid 3 onder g BW? Dit oordeel zal volgens de A-G altijd verweven zijn met aspecten van beoordelende en interpretatieve aard. De passages in de wetsgeschiedenis bij de Wwz waarin wordt gezegd dat de werkgever enige ruimte moet hebben bij de beslissing over het ontslag van de werknemer, moeten tegen deze achtergrond worden begrepen. Deze passages brengen volgens de A-G niet mee dat de rechter 'marginaal' toetst of sprake is van ongeschiktheid of van een verstoorde arbeidsverhouding. Zij betekenen slechts dat voor het bewijs van ongeschiktheid of een verstoorde arbeidsverhouding voldoende is dat deze voldoende annemelijk wordt uit de vaststaande feiten. ${ }^{18}$

Aan het begin van deze paragraaf merkten wij op dat de voorliggende procesrechtelijke vraag in cassatie was of de hoven het bewijsrecht hadden geschonden door de aanwezigheid van de redelijke grond aannemelijk te achten. De A-G behandelt de redelijke gronden als feiten waarop bewijsregels van toepassing zijn, geeft een

16. Zo'n aannemelijkheidsoordeel duidt er dus op dat de rechter vanwege de aard van de procedure geen nadere bewijslevering toestaat. Hij doet dan uitspraak op basis van de door partijen aangereikte informatie. In zulke procedures (denk aan kortgedingprocedures of ontbindingsprocedures oude stijl) beslist de rechter op basis van de processtukken, de bijgevoegde bewijsmiddelen en het verhandelde ter zitting. Het oordeel dat feiten 'aannemelijk' zijn geworden leidt er in deze categorie gevallen toe dat partijen niet de mogelijkheid krijgen nader bewijs te leveren van de gestelde feiten.

17. Zie de conclusie bij de Decor-beschikking, punt 3.27

18. Dit is dezelfde maatstaf die de A-G eerder in haar conclusies formuleerde voor feiten die het karakter hebben van conclusies of gevolgtrekkingen. bewijsregel en concludeert dat de hoven het bewijsrecht niet hebben geschonden.

Uit het bovenstaande leiden wij af dat een redelijke grond een rechtsfeit is dat door de werkgever gesteld en indien nodig bewezen moet worden. In de optiek van de A-G kan men dit bewijs leveren door de aanwezigheid van de redelijke grond voldoende aannemelijk te maken. Uiteraard doet het voorgaande er niet aan af dat ook andere feiten gesteld en, bij voldoende betwisting, bewezen moeten worden om tot een ontbinding te kunnen komen, zoals het feit dat herplaatsing niet mogelijk is of niet in de rede ligt.

\subsection{De uitspraken: de Hoge Raad geeft een} bewijsmaatstaf voor de redelijke gronden

Wij lezen de beschikkingen zo, dat de Hoge Raad de A-G volgt. De Hoge Raad bevestigt in beide beschikkingen eerst het oordeel uit de Mediant-beschikking dat 'het bewijsrecht' van toepassing is. ${ }^{19}$ De wettelijke bewijsregels brengen onder meer mee dat de werkgever 'de aan zijn ontbindingsverzoek ten grondslag liggende feiten en omstandigheden' zal moeten stellen en, bij betwisting, zal moeten bewijzen. Daaraan voegt de Hoge Raad - in navolging van de A-G - toe dat voor bewijs in het burgerlijk procesrecht niet steeds is vereist dat de te bewijzen feiten en omstandigheden onomstotelijk komen vast te staan, maar dat soms genoeg is dat deze voldoende aannemelijk worden. ${ }^{20}$ De Hoge Raad verwijst in zijn oordelen naar de conclusies van de A-G. ${ }^{21}$ Hij onderschrijft hiermee dus de hierboven besproken opvatting van de A-G. Feiten met het karakter van gevolgtrekkingen kunnen ook volgens de Hoge Raad worden bewezen door voldoende aannemelijk te maken dat ze voortvloeien uit andere feiten.

Volgt de Hoge Raad de A-G echter ook in zoverre dat hij oordeelt dat een redelijke grond dient te worden gekwalificeerd als een aan een ontbindingsverzoek ten grondslag liggend (rechts)feit of omstandigheid? Naar onze mening wordt dat niet volledig duidelijk, maar zijn daar wel goede aanwijzingen voor.

De onduidelijkheid zit in de overweging van de Hoge Raad 'dat de toepasselijkheid van de wettelijke bewijsregels moet worden onderscheiden van de vraag of is voldaan aan de maatstaf van artikel 7:669 lid 3 sub d of sub g BW.'22 De vraag of het bewijsrecht van toepassing is, is dus een andere dan de vraag wanneer zich een redelijke grond voordoet. Volgens de Hoge Raad dient de rechter in het kader van de beoordeling van de door de werkgever aangevoerde redelijke grond te onderzoeken

19. HR 23 december 2016, ECLI:NL:HR:2016:2998, NJ 2017/204 (Mediant).

20. Zie zowel de B\&C-beschikking als de Decor-beschikking, r.o. 3.4.2 en 3.4.3.

21. De Hoge Raad verwijst immers uitdrukkelijk naar de punten 3.24-3.25 en 3.27-3.29, waarin de A-G uitlegt dat 'Sommige feiten (...) naar hun aard sterk verweven [zijn] met oordelen of interpretaties en (...) slechts [kunnen] worden bewezen door aannemelijk te maken dat zij redelijkerwijs zijn af te leiden uit andere, meer "harde" feiten.'

22. De Hoge Raad spreekt zich niet uit over de andere redelijke gronden van art. 7:669 lid 3 BW. Toch menen wij dat dezelfde maatstaf moet worden aangelegd bij de beoordeling of een van de overige redelijke gronden zich voordoet. 
of, uitgaande van de feiten en omstandigheden die - zo nodig na bewijslevering - zijn komen vast te staan, in redelijkheid kan worden geoordeeld dat sprake is van deze door de werkgever aangevoerde redelijke grond. ${ }^{23}$ Dit oordeel van de Hoge Raad is voor tweeërlei uitleg vatbaar.

De Hoge Raad onderscheidt namelijk de vraag of een redelijke grond aanwezig is van de vraag of het wettelijke bewijsrecht van toepassing is. Je zou dit zo kunnen opvatten dat de Hoge Raad overweegt dat het oordeel dat een redelijke grond aanwezig is niet een bewijsbaar rechtsfeit, maar een rechtsoordeel is. In onze optiek is dat niet het geval. Wij menen dat de overwegingen van de Hoge Raad een bewijsmaatstaf bevatten. De Hoge Raad formuleert immers dezelfde maatstaf als de A-G: de rechter moet zowel volgens de A-G als van de Hoge Raad onderzoeken of 'uitgaande van de feiten en omstandigheden die - zo nodig na bewijslevering - zijn komen vast te staan, in redelijkheid kan worden geoordeeld dat sprake is van de door de werkgever aangevoerde ontslaggrond. ${ }^{24}$

Met andere woorden: eerst moet de rechter de meer 'harde' feiten vaststellen. Daarvoor gebruikt hij het volledige bewijsrecht. Vervolgens moet de rechter op basis van de vaststaande 'harde' feiten nagaan of in redelijkheid kan worden geoordeeld dat sprake is van de door de werkgever aangevoerde redelijke grond. Is dat het geval, dan oordeelt de rechter dat de aanwezigheid van de gestelde redelijke grond voldoende aannemelijk is geworden, dus dat de werkgever de gestelde redelijke grond heeft bewezen.

In dat kader oordeelde de Hoge Raad onlangs dat het oordeel in de Decor-beschikking meebrengt dat 'de werknemer die bewijs heeft aangeboden van door hem aangevoerde feiten en omstandigheden die zich lenen voor bewijslevering en die tot een ander oordeel kunnen leiden over de feiten en omstandigheden ten aanzien waarvan de werkgever de bewijslast draagt, tot levering van dat tegenbewijs moet worden toegelaten. ${ }^{25} \mathrm{Wij}$ lezen hierin een bevestiging van onze interpretatie van de 16 februari-beschikkingen. De Hoge Raad overweegt immers dat een werknemer toegelaten moet worden tot tegenbewijs dat tot een andere gevolgtrekking kan leiden dan die welke de werkgever voorstaat en waarvan de werkgever de bewijslast draagt (lees: de redelijke grond). In zoverre past deze overweging ook binnen de overwegingen van de A-G, dat 'als evengoed een ándere gevolgtrekking kan worden gemaakt, zal moeten worden geoordeeld dat het bewijs [van de redelijke grond, MJ \& JW] niet is geleverd.' 26

Hoe dan ook, de Hoge Raad heeft zich tot op heden nog niet expliciet uitgesproken over het principiële onderscheid dat wij in dit artikel maken. Zoals gezegd leiden wij uit het feit dat de Hoge Raad in de 16-februaribeschikkingen verwijst naar de relevante overwegingen van de A-G af dat de aanwezigheid van een redelijke grond in de optiek van de Hoge Raad een rechtsfeit is. Daarvoor vinden wij steun in de zojuist besproken recentere uitspraak. Doordat hierover ook anders kan worden gedacht, bespreken wij in de navolgende paragrafen of het systeem van de wet meebrengt dat de redelijke gronden rechtsgronden of rechtsfeiten zijn. Kort gezegd betogen wij hierna dat een redelijke grond een rechtsfeit is dat door de werkgever gesteld moet worden en, bij betwisting, bewezen (voldoende aannemelijk gemaakt). Wij leggen dit hieronder uit.

\section{Een redelijke grond is geen rechtsgrond}

\subsection{Feiten}

Partijen moeten op grond van artikel $21 \mathrm{Rv}$ alle feiten die relevant zijn voor de beslissing van de rechter (volledig en naar waarheid) aanvoeren, op straffe van de gevolgtrekkingen die de rechter geraden acht. Aan zijn beslissing mag de rechter op grond van artikel $149 \mathrm{Rv}$ geen andere feiten en omstandigheden ten grondslag leggen dan de feiten die partijen hebben aangedragen. Anders gezegd: alle feiten in de procedure, met uitzondering van feiten van algemene bekendheid en algemene ervaringsregels, ${ }^{27}$ moeten van de partijen afkomstig zijn. Daarbij maakt het in beginsel niet uit welke partij een feit aandraagt. ${ }^{28}$

\subsection{Rechtsfeiten en (feitelijke) grondslag}

Een eiser kan niet volstaan met het voorleggen van een bloot feitenbestand aan de rechter. Hij moet uitleggen wat hij ermee bedoelt. Hij moet structuur in de feiten aanbrengen, hij moet een kern aangeven die zijn vordering of verzoek ondersteunt. ${ }^{29}$ Voordat de rechter een vordering, verzoek of verweer kan honoreren, zal de verzoekende partij moeten stellen dat aan een of meer door hem gestelde feiten een rechtsgevolg is verbonden. Doordat een partij de feiten juridisch kwalificeert, ontstaat een rechtsfeit. De Bock geeft hiervan het volgende voorbeeld: 'Wanneer een partij stelt "de vrouw liet het raam openstaan" of "de auto is geleverd in december 2008", worden blote feiten gesteld. Maar deze blote feiten worden rechtsfeiten, wanneer daaraan een juridische of normatieve kwalificatie wordt gevoegd: "het was onvoorzichtig van de vrouw om het raam open te laten staan" of "de auto is te laat geleverd". Ook een gestelde overeenkomst is als een rechtsfeit aan te merken; dat
23. Zie zowel de B\&C-beschikking als de Decor-beschikking, respectievelijk r.o. 3.4.5 en 3.4.4.

24. Zie punt 3.39 van de conclusie en r.o. 3.4 .4 van de beschikking in de B\&C-zaak en punt 3.30 van de conclusie en r.o. 3.4.4 van de beschikking in de Decor-zaak.

25. HR 29 juni 2018, ECLI:NL:HR:2018:1045

26. Concl. A-G bij de Decor-beschikking, punt 3.27
27. Wij spreken hierna kortheidshalve van feiten en laten feiten van algemene bekendheid en ervaringsregels buiten beschouwing.

28. Zie ook M. Ahsmann, De weg naar het civiele vonnis, Den Haag: Boom Juridische uitgevers 2014, par. 4.9.

29. T.F.E. Tjong Tjin Tai, 'De rechterlijke vrijheid en de feitelijke grondslag', TCR 2002, p. 30. 
sprake is van een overeenkomst, houdt immers ook al een juridische kwalificatie in. ${ }^{30}$

Een feit of samentelling van feiten waaraan een juridische gevolgtrekking is verbonden, wordt dus een rechtsfeit genoemd. ${ }^{31}$ Sommige rechtsfeiten bestaan op hun beurt weer uit andere rechtsfeiten. Dit worden ook wel 'samengestelde rechtsfeiten' genoemd. ${ }^{32}$ Denk bijvoorbeeld aan de verbintenis uit onrechtmatige daad. Deze verbintenis is het rechtsgevolg van een samengesteld rechtsfeit, dat is opgebouwd uit verschillende rechtsfeiten: onrechtmatigheid, toerekenbaarheid, schade, causaliteit en relativiteit. ${ }^{33}$

Alle - al dan niet samengestelde - rechtsfeiten die door een partij worden gesteld om een vordering of verzoek toegewezen te krijgen vormen gezamenlijk de feitelijke grondslag. Artikel $24 \mathrm{Rv}$ bepaalt, zoals gezegd, dat de rechter een zaak niet mag onderzoeken en beslissen op een andere feitelijke grondslag dan die welke partijen aan hun vordering, verzoek of verweer ten gronde hebben gelegd. De grondslag bestaat dus alleen uit de rechtsfeiten die door een partij worden gesteld om een bepaald rechtsgevolg in te roepen.

In dit kader is het onderscheid tussen artikel $149 \mathrm{Rv}$ en artikel $24 \mathrm{Rv}$ verhelderend. Op grond van artikel $149 \mathrm{Rv}$ mag een rechter geen feiten aan zijn beslissing ten grondslag leggen die partijen niet zelf in het geding hebben gebracht. Artikel $24 \mathrm{Rv}$ bepaalt dat een rechter zijn beslissing niet mag baseren op rechtsfeiten waarop partijen geen beroep hebben gedaan in het kader van hun vordering, verzoek of verweer. ${ }^{34}$ Niet alle feiten die op grond van artikel $149 \mathrm{Rv}$ vast zijn komen te staan, mogen dus op grond van artikel $24 \mathrm{Rv}$ worden gebruikt om een vordering, verzoek of verweer te honoreren. Artikel $24 \mathrm{Rv}$ drukt dus het beginsel van partijautonomie uit. ${ }^{35}$ Partijen beslissen zelf in welk licht zij de feiten willen zetten. Maar het verbod op rechterlijke aanvulling van de feitelijke grondslag beschermt ook de wederpartij, die immers wel moet weten waartegen zij zich moet verweren. ${ }^{36}$

\subsection{Rechtsgronden}

Van de feitelijke grondslag moeten de rechtsgronden worden onderscheiden. Zoals gezegd mag de rechter de feitelijke grondslag krachtens artikel $24 \mathrm{Rv}$ niet aanvullen. Partijen bepalen immers zelf waarover ze procederen. De rechter móét echter op grond van artikel $25 \mathrm{Rv}$ zelfstandig - en in beginsel onafhankelijk van welke rechtsgronden partijen daartoe hebben aangevoerd - nagaan of

30. R.H. de Bock, Tussen waarheid en onzekerheid: over het vaststellen van feiten in de civiele procedure (diss. Tilburg), Deventer: Kluwer 2011, p. 117

31. Zie o.a. Asser/Hartkamp \& Sieburgh 6-III 2014/2-3 en R.H. de Bock, Tussen waarheid en onzekerheid: over het vaststellen van feiten in de civiele procedure (diss. Tilburg), Deventer: Kluwer 2011, p. 117.

32. Zie bijv. A.R. Bloembergen, Schadevergoeding bij onrechtmatige daad (diss. Utrecht), Deventer: Kluwer 1965.

33. Concl. A-G bij HR 1 mei 2015, NJ 2015, 425.

34. Zie o.a. HR 10 februari 2017, NJ 2017/101; HR 10 februari 2006, NJ 2006/241 en HR 24 juni 2005, NJ 2006/46.

35. Zie o.m. Asser Procesrecht/Asser 3 2013/91.

36. T.F.E. Tjong Tjin Tai, 'De rechterlijke vrijheid en de feitelijke grondslag', TCR 2002, p. 32 de feitelijke grondslag een vordering, verzoek of verweer kan doen slagen. Indien partijen daarvoor geen - of de verkeerde - rechtsgrond naar voren hebben gebracht, dient de rechter deze ambtshalve toe te passen. ${ }^{37}$ De rechter mag echter alleen rechtsgronden aanvullen voor zover die van toepassing kunnen zijn op hetgeen partijen feitelijk ten grondslag hebben gelegd aan hun verzoek, vordering of verweer.

Het staat de rechter dus niet vrij rechtsgronden toe te passen op (rechts)feiten die weliswaar volgen uit het geding, maar die door de desbetreffende partij niet aan haar vordering of verweer ten grondslag zijn gelegd. Zo oordeelde de Hoge Raad in 2004 samengevat dat het hof de aansprakelijkheid van een bemiddelaar niet had mogen aannemen op grond van artikel 6:76 BW (aansprakelijkheid voor fouten van een hulppersoon). Het hof had uit de vaststaande feiten weliswaar opgemaakt dat de bemiddelaar een hulppersoon had ingeschakeld die een fout had gemaakt, maar dit rechtsfeit was door de eiser niet aangevoerd of ingeroepen als reden voor aansprakelijkheid. Dit feit ('er is een hulppersoon') bleek dus wel uit het geding, maar lag niet aan de vordering ten grondslag. De eiser had immers enkel gesteld dat de bemiddelaar aansprakelijk was omdat die zelf een fout zou hebben gemaakt, niet omdat hij het risico droeg voor de fout van een door hem ingeschakelde derde. Om die reden mocht het hof artikel 6:76 $\mathrm{BW}$ niet ambtshalve toepassen. $\mathrm{Nu}$ het hof dit wel had gedaan, had het de feitelijke grondslag van de eiser aangevuld. Daarmee deed het de wederpartij tekort in haar recht zich naar behoren te kunnen verdedigen. ${ }^{38}$

De rechter mag dus alleen rechtsgronden aanvullen voor zover die van toepassing zijn op (rechts)feiten die niet enkel zijn komen vast te staan, maar die ook door partijen ten grondslag zijn gelegd aan een vordering, verzoek of verweer. Met andere woorden: als een partij zelf geen rechtsgevolg verbindt aan een bepaald feit, dan mag de rechter dat niet uit eigen beweging doen. Dat mag alleen als een partij het gevolg van een bepaald rechtsfeit inroept en zich daarbij niet - of op een verkeerde rechtsgrond beroept. Stel dat de eiser in het bovenstaande voorbeeld had gesteld dat de bemiddelaar aansprakelijk was omdat ook de fout van een door hem ingeschakelde derde voor zijn risico komt. Dan had het hof de rechtsgrond wel mogen aanvullen. Het hof had dan namelijk niet eerst de feitelijke grondslag van de vordering aan hoeven vullen. Het rechtsgevolg schadevergoeding zou dan al door de eiser zijn verbonden aan het inzetten van een slechte hulppersoon.

\subsection{De redelijke gronden}

Mede in het licht van het bovenstaande menen wij dat een redelijke grond moet worden gezien als rechtsfeit en niet als rechtsgrond. Een redelijke grond is immers een (samenstelling van) feit(en) dat, in samenhang met

37. Zie o.a. HR 15 mei 1998, NJ 1998/625 (Van Rooij/Erven Van der Sluijs).

38. HR 1 oktober 2004, NJ 2005/92 (Poort c.s./Stoppels). Zie in dit kader ook: 10 februari 2017, NJ 2017/101, HR 10 februari 2006, NJ 2006/241 en HR 24 juni 2005, NJ 2006/46. 
andere rechtsfeiten, maakt dat de werkgever een beroep kan doen op de rechtsgrond van artikel 7:671b BW om ontbinding van de arbeidsovereenkomst te verzoeken. Het is hierbij van belang onderscheid te maken tussen de redelijke gronden enerzijds en anderzijds de (juridische) grondslag waarop de rechter op verzoek van de werkgever de arbeidsovereenkomst kan ontbinden.

De rechtsgrond voor ontbinding van de arbeidsovereenkomst op verzoek van de werkgever is immers niet de aanwezigheid van de redelijke grond zelf, maar het bepaalde in artikel 7:671b BW. ${ }^{39}$ Het eerste lid bevat het eerste vereiste voor ontbinding, namelijk dat een van de redelijke gronden uit artikel 7:669 lid $3 \mathrm{BW}$ aanwezig is. Het tweede en het derde vereiste voor ontbinding treft men in het tweede lid van artikel 7:671b BW. De werkgever moet op grond daarvan óók hebben voldaan aan de overige voorwaarden uit artikel 7:669 BW. Herplaatsing moet dus niet mogelijk zijn of niet in de rede liggen en er dient verder geen sprake te zijn van een opzegverbod. Een werkgever die een arbeidsovereenkomst door de rechter wil laten ontbinden, zal aan zijn ontbindingsverzoek in ieder geval het volgende ten grondslag moeten leggen wil hij zijn beroep op artikel 7:671b BW laten slagen:

i. $\quad$ Er is een redelijke grond uit artikel 7:669 lid 3 onder $\mathrm{c} \mathrm{t} / \mathrm{m} \mathrm{h} \mathrm{BW}$;

ii. herplaatsing is niet mogelijk of ligt niet in de rede; ${ }^{40}$ en

iii. er is geen sprake van een wettelijk opzegverbod. ${ }^{41}$

Samen vormen de rechtsfeiten genoemd onder (i) $t / m$ (iii) de minimaal aan te dragen feitelijke grondslag die nodig is voor een succesvol ontbindingsverzoek. Als de werkgever een van deze elementen niet aan zijn ontbindingsverzoek ten grondslag legt, kan de rechter de arbeidsovereenkomst dus niet ontbinden zonder daarbij ook de feitelijke grondslag van het verzoek aan te vullen. Dit betekent dat als door de werkgever, bijvoorbeeld, niet is gesteld dat herplaatsing niet mogelijk is of in de rede ligt, een essentieel element voor het uitspreken van de verzochte ontbinding ontbreekt. De rechter mag in dat geval de arbeidsovereenkomst niet op de door de werkgever aangedragen feitelijke grondslag ontbinden. Anders gezegd: het rechtsfeit 'herplaatsing is niet mogelijk of ligt niet in de rede' is niet gesteld en ligt daarmee dus niet ten grondslag aan het verzoek van de werkgever. De rechter kan dus - gelet op artikel $24 \mathrm{Rv}-$ de

39. Wij laten de mogelijkheden tot ontbinding uit art. 7:671b lid 1 onder b en c BW buiten beschouwing.

40. Voor de volledigheid: dit geldt ook bij de e-grond. Formeel gezien dient immers ook bij een opzegging of ontbinding op de e-grond te zijn voldaan aan het vereiste dat herplaatsing niet mogelijk is of niet in de rede ligt. Er zijn omstandigheden denkbaar waaronder de werknemer zich zou kunnen beroepen op de derogerende werking van de redelijkheid en billijkheid van art. 6:248 lid 2 BW om het beroep van de werkgever op de subregel 'Herplaatsing ligt in ieder geval niet in de rede wanneer sprake is van verwijtbaar handelen of nalaten' te blokkeren.

41. Voor de volledigheid: de kantonrechter kan uiteraard ook ontbinden indien is voldaan aan de eis van art. 7:671b lid 6 BW, dus als het verzoek geen verband houdt met de omstandigheden waarop het opzegverbod ziet of als er sprake is van omstandigheden die van dien aard zijn dat de arbeidsovereenkomst in het belang van de werknemer behoort te eindigen. arbeidsovereenkomst niet ontbinden op de door de werkgever aangevoerde feitelijke grondslag. ${ }^{42}$

Bennaars en Quist lijken dit in hun onlangs in $T A P$ verschenen artikel anders te zien. Zij schrijven dat de rechter de arbeidsovereenkomst niet kan ontbinden zonder dat een voldragen redelijke grond aanwezig is en dat de rechter bovendien - discussies over de herplaatsingsplicht en opzegverboden daargelaten - gehouden is de arbeidsovereenkomst te ontbinden indien zich een voldragen redelijke grond voordoet. ${ }^{43}$ De auteurs lijken ervan uit te gaan dat de aanwezigheid van een redelijke grond zowel een noodzakelijke als voldoende voorwaarde - en daarmee de rechtsgrond - is voor ontbinding van de arbeidsovereenkomst.

Wij menen echter dat het vereiste dat een redelijke grond aanwezig moet zijn wél een noodzakelijke voorwaarde is voor ontbinding van de arbeidsovereenkomst, maar nog geen voldoende voorwaarde. Het vereiste dat herplaatsing niet mogelijk is of niet in de rede ligt en de benodigde afwezigheid van een opzegverbod zijn in het systeem van de wet even zo noodzakelijke voorwaarden voor ontbinding. Het tweede lid van dit artikel is immers duidelijk:

'De kantonrechter kan het verzoek, bedoeld in lid 1, slechts inwilligen indien aan de voorwaarden voor opzegging van de arbeidsovereenkomst, bedoeld in artikel 669 , is voldaan en er geen opzegverboden als bedoeld in artikel 670 of met deze opzegverboden naar aard en strekking vergelijkbare opzegverboden in een ander wettelijk voorschrift gelden.'

De enkele aanwezigheid van een redelijke grond leidt dus niet tot het ontstaan van rechten of plichten. Anders gezegd: de door arbeidsrechtjuristen vaak gebruikte uitdrukking 'de kantonrechter ontbond op de e-grond (of g-grond, of d-grond), is strikt genomen onnauwkeurig. ${ }^{44}$ De kantonrechter kan uitsluitend ontbinden op grond van artikel 7:671b lid 1 aanhef en onder a t/m c jo artikel 7:671b lid $2 \mathrm{BW}$.

Wij onderschrijven de stelling van Bennaars en Quist dat de redelijke gronden als een regel van positief recht zijn te beschouwen, ${ }^{45}$ maar volgens ons rechtvaardigt dit enkele gegeven niet de conclusie dat de rechter de rede-

42. Een interessante observatie is dat de rechter de arbeidsovereenkomst dus niet mag ontbinden als de werkgever in zijn verzoek niet stelt dat de werknemer niet arbeidsongeschikt is, althans dat arbeidsongeschiktheid niet de reden is voor ontbinding. Wij geven onmiddellijk toe dat in de praktijk standaard in ieder verzoekschrift staat dat van een opzegverbod geen sprake is. Dat doet aan ons betoog niets af, sterker nog: het onderschrijft juist dat iedere arbeidsrechtjurist instinctief weet dat dit element op zijn minst genoemd moet worden wil de arbeidsovereenkomst ontbonden kunnen worden.

43. J.H. Bennaars \& J.P. Quist, 'Ambtshalve aanvulling van rechtsgronden in de ontbindingsprocedure?', TAP 2018/99, p. 12.

44. Het is, gelet op de tekst van de wet, wel een begrijpelijke uitdrukking De formulering van art. 7:671 b lid 1 onderdelen a t/m c BW suggereert immers wel dat wordt ontbonden 'op grond van' een redelijke grond: 'De kantonrechter kan op verzoek van de werkgever de arbeidsovereenkomst ontbinden: (a) op grond van artikel 669, lid 3, onderdelen c tot en met $\mathrm{h}$

45. J.H. Bennaars \& J.P. Quist, 'Ambtshalve aanvulling van rechtsgronden in de ontbindingsprocedure?', TAP 2018/99, p. 12. 
lijke gronden ambtshalve kan toepassen. Zoals Bennaars en Quist zelf al opmerken, heeft de feitelijke grondslag immers zowel een feitelijke als een juridische component. ${ }^{46}$ Ons privaatrecht kent allerlei rechtsregels die zien op de vraag wanneer bepaalde blote feiten tezamen een bepaald rechtsfeit vormen, dat vereist is om een bepaald rechtsgevolg te doen intreden. Wij leggen dit uit aan de hand van een vergelijking met de rechtsfiguur 'causaliteit' in het onrechtmatigedaadsrecht.

Niemand zal bijvoorbeeld raar opkijken als wij stellen dat een vordering uit hoofde van onrechtmatige daad moet worden afgewezen als de eiser vergeten is het causaal verband tussen de onrechtmatige gedraging en zijn schade te stellen. Het causaal verband tussen de onrechtmatige gedraging en de schade is immers een noodzakelijke voorwaarde voor toewijzing van de vordering. Het systeem van stelplicht en bewijslast brengt mee dat een vordering uit hoofde van onrechtmatige daad niet kan worden toegewezen als het element 'causaal verband' niet is gesteld. Dat er rechtsregels zijn die bepalen wanneer sprake is van het rechtsfeit causaal verband, doet daar niet aan af. ${ }^{47}$ Wij menen dat de regel dat voor ontbinding van de arbeidsovereenkomst een redelijke grond aanwezig moet zijn, van dezelfde orde is als de regel dat causaal verband vereist is voor schadevergoeding uit hoofde van onrechtmatige daad. Dat geldt ook voor de onmogelijkheid van herplaatsing of voor de afwezigheid van een opzegverbod. Net zoals de rechter de gedaagde alleen mag veroordelen tot schadevergoeding als het causaal verband is gesteld, mag de rechter de arbeidsovereenkomst alleen ontbinden als ook is gesteld dat herplaatsing niet mogelijk is of niet in de rede ligt. Maar wat nu als wel gesteld is dat zich 'een redelijke grond' voordoet, maar niet gespecificeerd is welke, of als de ene redelijke grond is gesteld maar de rechter vindt dat zich een andere voordoet? Een vergelijkbare vraag was aan de orde in het arrest van de Hoge Raad van 26 september 1997 over ontslag op staande voet. $^{48}$

Zoals bekend is voor een rechtsgeldig ontslag op staande voet onder andere vereist dat een dringende reden aanwezig is. Maar de ene dringende reden is de andere niet. Illustratief is het geval waarin werknemer was betrapt met mobiele telefoons van zijn werkgever en daarvoor op staande voet was ontslagen wegens, kort gezegd, diefstal. De werknemer had zich verweerd door te stellen dat hij de telefoons op de zwarte markt in Beverwijk had gekocht. De rechtbank had de vraag of de diefstal was bewezen in het midden gelaten, en had de vorderingen van de werknemer op grond van een andere dringende reden afgewezen. Volgens de rechtbank was de werknemer, zelfs als zijn stelling over de zwarte markt juist was

46. R.H. de Bock, Tussen waarheid en onzekerheid: over het vaststellen van feiten in de civiele procedure (diss. Tilburg), Deventer: Kluwer 2011, p. 117

47. Een ander voorbeeld is het rechtsfeit 'overeenkomst'. Een overeenkomst komt tot stand door aanbod en aanvaarding (art. 6:217 lid 1 BW). Het bestaan van een overeenkomst kan echter ook onderwerp zijn van een bewijsopdracht. Vgl. Asser Procesrecht/Asser 3 2013/32.

48. HR 26 september 1997, NJ 1998/420. geweest, zo nalatig ten opzichte van PTT Telecom gebleven dat dit voldoende reden vormde voor een ontslag op staande voet. De Hoge Raad oordeelde dat de rechtbank daarmee - in strijd met het verbod daarop de feitelijke gronden had aangevuld door een ontslaggrond te aanvaarden op grond van feiten die weliswaar volgden uit het geding, maar die door de werkgever niet ten grondslag waren gelegd aan de dringende reden. Daarmee was de rechtbank buiten de rechtsstrijd van partijen getreden. Een interessant detail hierbij is dat uit de gedingstukken wel bleek dat partijen het over dit punt hadden gehad. De rechter mocht zijn beslissing hier echter niet op baseren. De werkgever had zich namelijk niet beroepen op het rechtsfeit 'dringende reden, bestaande uit nalatigheid', maar op het rechtsfeit 'dringende reden, bestaande uit diefstal'.

Wij menen dat dit arrest van belang is voor het onderwerp van dit artikel. Als de rechter zich al schuldig maakt aan een verboden aanvulling van de feitelijke grondslag wanneer hij een andere dringende reden aanneemt dan de werkgever aanvoert, dan geldt dat toch ook bij de redelijke gronden? Deze omvatten immers een veel breder scala aan situaties dan artikel 7:678 BW. Het Hof Arnhem-Leeuwarden, ${ }^{49}$ de Kantonrechter Den Haag $^{50}$ en de Kantonrechter Enschede ${ }^{51}$ lijken deze opvatting te delen. ${ }^{5253}$

Wij menen dan ook dat Van der Kind terecht in 2016 opmerkte dat de benadering dat de rechter binnen de grenzen van artikel 7:671b lid 1 onder a $\mathrm{BW}$ de redelijke gronden zou mogen aanvullen een '(extreme) keerzijde' heeft. ${ }^{54}$ De werkgever zou in dat geval in zijn ontbindingsverzoek immers kunnen volstaan met het geven van een beschrijving van alle feiten en omstandigheden. De rechter zou dan moeten kiezen welke redelijke grond (het beste) past bij die beschrijving. Dit zou betekenen dat de rechter het verzoek van de werkgever zou mogen honoreren zonder dat de werkgever heeft uitgelegd hoe hij tegen de feiten aankijkt (welk rechtsfeit zich voordoet). ${ }^{55}$ Uit het voorgaande is hopelijk duidelijk geworden dat wij menen dat de werkgever hiermee zou verzuimen de feitelijke grondslag voor zijn verzoek aan te

49. Hof Arnhem-Leeuwarden 4 maart 2016, ECLI:NL:GHARL:2016:1716, JAR 2016/109.

50. Ktr. Den Haag 10 mei 2016, ECLI:NL:RBDHA:2016:5102, AR 2016/1359.

51. Ktr. Enschede 13 april 2017, ECLI:NL:RBOVE:2017:1629.

52. Vestering en Wetzels hebben enkele kanttekeningen geplaatst bij deze uitspraken. Zie: P.G. Vestering en W.J.J. Wetzels, Praktisch arbeidsprocesrecht onder de WWZ, Den Haag: Sdu Uitgevers 2018, p. 44-45. Vestering en Wetzels gaan er echter kennelijk wel van uit dat de redelijke gronden rechtsgronden zijn, nu ze het oordeel van het Hof ArnhemLeeuwarden in strijd met art. $25 \mathrm{Rv}$ achten.

53. Niet alle kantonrechters denken hierover hetzelfde, zie anders: Ktr. Tilburg 8 april 2016, ECLI:NL:RBZWB:2016:2143, RAR 2016/108; Ktr. Maastricht 9 mei 2016, ECLI:NL:RBLIM:2016:3938, AR 2016/1408.

54. O. van der Kind, 'De 671b-procedure: een keurslijf voor de kantonrechter?' (annotatie bij Ktr. Tilburg 8 april 2016), AR Updates 2016/0369.

55. Vergelijk ook Van Schilfgaarde: 'Aan het feit op zichzelf, het blote feit, heeft de rechter geen boodschap. (...) De feiten moeten worden aangekleed, willen zij als rechtsfeit kunnen functioneren. Een civiele procedure, waarin partijen tegen over elkaar staan, is grotendeels een strijd om die aankleding.' Uit: P. van Schilfgaarde, 'Feiten en rechtsoordelen (I)', WPNR 2000/6396 p. 227-232 
dragen. ${ }^{56}$ Wij hebben echter ook een meer praktisch, op de ongelijkheidscompensatie geënt, bezwaar.

Als deze benadering zou worden toegestaan, dan zouden werknemers in hun verweer moeten anticiperen op alle mogelijke redelijke gronden. In dit kader durven wij de door Van der Kind genoemde (extreme) keerzijde nog wat aan te scherpen. De rechter zou ook een ontbindingsverzoek na een afgewezen ontslagvergunningsaanvraag (op grond van artikel 7:671b lid 1 onder b BW) mogen toekennen indien hij van oordeel is dat ondanks dat een bedrijfseconomische reden ten grondslag is gelegd - uit de aangevoerde feiten en omstandigheden kan worden opgemaakt dat sprake is van bijvoorbeeld disfunctioneren, een verstoorde arbeidsverhouding of verwijtbaar handelen. Het behoeft geen toelichting dat dit in strijd zou zijn met de, hierboven in $\$ 3.2$ genoemde, functie van artikel $24 \mathrm{Rv}$ dat de verweerder moet weten waartegen hij zich moet verweren. In het arbeidsrecht zou dat argument nog wat extra gewicht moeten krijgen.

Dit alles maakt dat wij concluderen dat een redelijke grond een rechtsfeit is en niet een rechtsgrond. De aanwezigheid van een specifieke redelijke grond zal door de werkgever moeten worden gesteld en, bij betwisting, bewezen. Dit brengt mee dat de rechter de redelijke gronden niet ambtshalve mag aanvullen.

$\mathrm{Bij}$ het bovenstaande past de kanttekening dat de feitenrechter de feitelijke grondslag dient te interpreteren, waarbij een bepaalde welwillendheid past. ${ }^{57}$ Ons betoog moet dus niet zo worden begrepen dat de werkgever al 'nat gaat' als hij verzuimt expliciet de redelijke grond aan te wijzen waarop hij zich beroept. Stel dat een werkgever ontbinding van een arbeidsovereenkomst verzoekt. Daarbij stelt hij gemotiveerd het volgende: de werknemer doet zijn werk niet goed; dit komt niet doordat de werknemer ziek of ongeschoold is; de werknemer is vaak op de erbarmelijke kwaliteit van zijn werk gewezen; er is geen ander werk voor de werknemer en overigens is er ook geen opzegverbod. De werkgever verzuimt alleen expliciet het etiket 'd-grond' op deze stellingen te plakken. De rechter zou dan bijvoorbeeld kunnen overwegen 'de werkgever heeft daarmee kennelijk tot uitdrukking gebracht dat de d-grond aanwezig is. ${ }^{58}$ De werkgever moet uiteraard wel alle benodigde rechtsfeiten hebben gesteld. ${ }^{59}$ Hiermee vult de rechter

56. Zie T.F.E. Tjong Tjin Tai, 'Waarheid in het burgerlijk proces', NJB 2012/1264 voor een mooie analogie. Tjong Tjin Tai schrijft dat de civiele procedure er, simpel gezegd om draait dat 'partijen ieder een verhaal voorleggen, en aan de rechter de keuze voorleggen welk verhaal het ware is, maar dat de rechter vaak geneigd is in een verhaal te gaan sleutelen door de feiten net iets anders te interpreteren en te belichten dan partijen zelf doen; hij herschrijft dan het verhaal. Hij rechtvaardigt dit dan door er op te wijzen dat de afloop toch hetzelfde blijft en het plot hierdoor plausibeler wordt. Maar is het dan nog wel het verhaal van de partij? Prevaleert de autonomie van de auteur of de rol van de rechter?' In het voorbeeld van Van der Kind heeft de werkgever het schrijven van het verhaal volledig aan de rechter gelaten.

57. Dit is vaste jurisprudentie, zie bijvoorbeeld HR 12 augustus 2016, RvdW 2016/909

58. Zie M. Ahsmann, De weg naar het civiele vonnis, Den Haag: Boom Juridische Uitgevers 2014, par. 4.9.

59. Vestering en Wetzels lijken een vergelijkbare mening toegedaan. dus niet de feitelijke grondslag of de rechtsgronden aan. Hij legt slechts de stellingen die de werkgever heeft ingenomen uit.

\section{Uitstapje: het wetsvoorstel arbeidsmarkt in balans}

\subsection{De Wab - toevoeging cumulatiegrond aan artikel 7:669 lid $3 \mathrm{BW}$}

Op 9 april 2018 werd de Wab aangeboden ter internetconsultatie. ${ }^{60}$ Met de Wab beoogt het kabinet het voor werkgevers aantrekkelijker te maken om werknemers in (vaste) dienst te nemen. Een van de maatregelen die het kabinet daartoe voorstelt is het invoeren van de zogeheten cumulatiegrond, ook wel: de 'i-grond'.

Blijkens de concept-memorie van toelichting meent de regering dat werkgevers op basis van de huidige redelijke gronden niet het vertrouwen hebben 'dat ze een werknemer kunnen ontslaan in een situatie als een einde van de arbeidsovereenkomst redelijkerwijs aan de orde is. ${ }^{\text {}}{ }^{61} \mathrm{De}$ aan de $\mathrm{W}$ wz ten grondslag liggende gedachte dat niet kan worden ontbonden op grond van een optelsom van op zichzelf onvoldragen redelijke gronden, leidt er in de optiek van de regering toe dat rechters niet kunnen ontbinden in situaties waarin in redelijkheid niet van de werkgever kan worden gevergd om de arbeidsovereenkomst te laten voortduren. Rechters kunnen volgens de regering dan ook onvoldoende maatwerk leveren onder het huidige recht. ${ }^{62}$

Om die reden wordt in de huidige redactie in het conceptwetsvoorstel aan de opsomming van redelijke gronden van artikel 7:669 lid 3 onder a t/m h BW een onderdeel 'i' toegevoegd:

'i. een combinatie van omstandigheden genoemd in twee of meer van de gronden, bedoeld in de onderdelen c tot en met $h$, die zodanig is dat van de merkgever in redelijkheid niet kan worden gevergd de arbeidsovereenkomst te laten voortduren.'

Daarnaast wordt aan artikel 7:671b BW een nieuw lid 8 toegevoegd (de huidige leden 8,9 en 10 schuiven één lid op) dat als volgt zal komen te luiden:

'8. Indien de kantonrechter de arbeidsovereenkomst ontbindt op grond van artikel 669, lid 3, onderdeel $i$, kan hij aan de merknemer een vergoeding toekennen van ten hoogste de helft van de vergoeding die de perkgever op grond van artikel 673, leden 1 en 3, aan de werknemer is verschuldigd.'

60. Conceptvoorstel van wet tot wijziging van Boek 7 van het Burgerlijk Wetboek, de Wet allocatie arbeidskrachten door intermediairs, de Wet financiering sociale verzekeringen en enige andere wetten om de balans tussen vaste en flexibele arbeidsovereenkomsten te verbeteren (Wet arbeidsmarkt in balans), zie: www.internetconsultatie.nl/arbeidsmarkt in_balans.

61. Concept-MvT Wab, p. 57

62. Concept-MvT Wab, p. 60 
De regering schrijft in de concept-memorie van toelichting bij de Wab dat de cumulatiegrond, net als de andere redelijke gronden, op grond van artikel $25 \mathrm{Rv}$ ook ambtshalve door de rechter kan worden toegepast. In de visie van de regering beoordeelt de rechter op grond van de aangevoerde feiten of de situatie onder een van de redelijke gronden valt, ook als die redelijke grond niet is aangevoerd. Baseert de werkgever een ontbindingsverzoek op een van de gronden genoemd in artikel 7:669 lid 3 onder $\mathrm{c} \mathrm{t} / \mathrm{m} \mathrm{h} \mathrm{BW}$, dan kan de rechter volgens de regering op grond van de aangevoerde feiten en omstandigheden ambtshalve tot het oordeel komen dat ontbonden moet worden op basis van de cumulatiegrond. De regering acht het omgekeerde ook mogelijk. De regering meent dat de rechter, wanneer is verzocht tot ontbinding op de cumulatiegrond, ambtshalve kan oordelen dat de in dat kader aangevoerde omstandigheden moeten leiden tot een ontbinding op grond van een van de andere redelijke gronden voor ontslag die genoemd zijn in artikel 7:669 lid 3 onder a t/m h. ${ }^{63}$

Gelet op het hierboven gevoerde betoog menen wij dat deze passage in de concept-memorie van toelichting bij de Wab uitgaat van een verkeerde wetsopvatting. De rechter kan de redelijke gronden niet ambtshalve aanvullen. Redelijke gronden zijn immers rechtsfeiten die door de rechter niet mogen worden aangevuld.

\section{Conclusie}

Gelet op het bovenstaande vragen wij ons af of vol te houden is dat de rechter een redelijke grond, waaronder dus de voorgestelde cumulatiegrond, ambtshalve mag toepassen. Dit lijkt het systeem van het burgerlijk procesrecht te miskennen. 